$\begin{array}{ll}\text { Research Square } & \text { Preprints are preliminary reports that have not undergone peer review. } \\ \text { They should not be considered conclusive, used to inform clinical practice, } \\ \text { or referenced by the media as validated information. }\end{array}$

\title{
Recurrent Uterine Tumors Resembling Ovarian Sex-Cord Tumors with The Growth Regulation by Estrogen in Breast Cancer 1-Nuclear Receptor Coactivator 2 Fusion Gene: A Case Report and Literature Review
}

\author{
Bin Chang ( $\sim$ binchang7551@163.com ) \\ Fudan University Shanghai Cancer Center \\ Qianming Bai \\ Fudan University, Shanghai Cancer Center \\ Lin Liang \\ Fudan University Shanghai Cancer Center \\ Huijuan Ge \\ Fudan University Shanghai Cancer Center \\ Qianlan Yao \\ Fudan University Shanghai Cancer Center
}

\section{Case Report}

Keywords: Uterine tumor resembling ovarian sex-cord tumor, growth regulation by estrogen in breast cancer 1-nuclear receptor coactivator 2 fusion gene, growth regulation by estrogen in breast cancer 1-rearrangement, recurrence, case report

Posted Date: July 9th, 2020

DOl: https://doi.org/10.21203/rs.3.rs-40713/v1

License: () (7) This work is licensed under a Creative Commons Attribution 4.0 International License. Read Full License

Version of Record: A version of this preprint was published on September 14th, 2020. See the published version at https://doi.org/10.1186/s13000-020-010258. 


\section{Abstract}

Background: Uterine tumors resembling ovarian sex-cord tumors (UTROSCTs) are rare mesenchymal neoplasms predominantly arising in perimenopausal and postmenopausal women. UTROSCTs with growth regulation by estrogen in breast cancer 1 (GREB1)-rearrangement or GREB1-rearranged uterine tumors are exceptionally rare, with only 12 previously reported cases. Here, we report a case of UTROSCT with the GREB1-nuclear receptor coactivator 2 (NCOA2) fusion gene.

Case Presentation: A 57-year-old woman presented with a 10.0-cm uterine mass. The tumor was composed of short spindle or epithelioid cells, arranged in diffused sheets, nested, and trabecular/cordlike. The tumor harbored the GREB1-NCOA2 fusion gene, as confirmed by RNA sequencing. The tumor recurred in the pelvis at 30 months after the initial diagnosis. We also compared the clinical and pathologic features of this case with those of the 12 previously published uterine GREB1-rearranged tumors. Of the combined 13 cases (present case and 12 previous cases), the mean age of patients was 64.8 years (range, 51-74 years). Of the nine reported cases of GREB1-rearranged tumor with follow up, four cases recurred or metastasized (44.4\%). Microscopically, most tumors (10/12, 83.3\%) showed infiltrative growth, and two were well demarcated. Mitotic figures ranged from 0 to 14 per 10 high-power fields (2 mm²; mean: 3.6). Lymphovascular invasion and necrosis were each present in two cases $(2 / 12,16.7 \%$ and $2 / 7,28.6 \%$, respectively).

Conclusions: This case provided further evidence that UTROSCTs with GREB1-rearrangement may have a high risk of recurrence. Further studies are necessary to clarify the clinical features of this type of tumor, particularly the prognosis, potential treatment, and range of possible molecular events.

\section{Introduction}

Uterine tumors resembling ovarian sex-cord tumors (UTROSCTs) are rare mesenchymal neoplasms that predominantly arise in perimenopausal and postmenopausal women. Recently, new fusion genes were identified in UTROSCTs, including estrogen receptor 1 (ESR1)-nuclear receptor coactivator (NCOA3), ESR1-NCOA2, growth regulation by estrogen in breast cancer 1 (GREB1)-NCOA1, GREB1-NCOA2, GREB1-catenin beta 1 (CTNNB1), GREB1-nuclear receptor subfamily 4 group A member 3 (NR4A3), and GREB1-synovial sarcoma translocation, chromosome 18 (SS18) [1-4]. Clinically, UTROSCT is regarded as a tumor of low malignant potential (5.9\% recurrence rate) [5]. However, a recent large series reported that $23.5 \%$ of UTROSCT behaved in a malignant manner [6]. Due to its rarity and the limited follow-up information for available cases, the intrinsic molecular mechanisms of UTROSCT cases with different clinical behaviors are still unclear. Lee et al. found that GREB1-rearranged uterine tumors may have a higher tendency of aggressive behaviors [4]. Herein, we report a case of recurrent UTROSCT with the GREB1-NCOA2 fusion gene, summarize the cases reported to date, and discuss the clinical treatment options.

\section{Case Presentation}

A 57-year-old postmenopausal woman presented with a 10.0-cm uterine mass, which was suspected to be uterine leiomyoma on B-scan ultrasonography. The mass was identified on physical examination, and there were no clinical manifestations. The patient underwent a total hysterectomy with bilateral salpingooophorectomy. Gross examination showed an intramural, $10.0 \times 8.5 \times 8.0 \mathrm{~cm}$, yellow, greyish white, soft and fleshy, well-circumscribed mass. Both ovaries and fallopian tubes were grossly normal.

Histologically, the mass exhibited myometrial invasion, and the tumor was arranged in diffused sheets mimicking low-grade endometrial stromal sarcoma (45\%), nested (30\%), trabecular/cordlike (20\%; Figure 1A). Additionally, the mass showed anastomotic glandular growth patterns (5\%; Figure 1B). The tumor was composed of short spindle or epithelioid cells with scant eosinophilic cytoplasm and round to ovoid bland vesicular nuclei with one to two small distinct nucleoli (Figure 1C). The nuclei were minimally atypical, and the mitotic rate was approximately 3 mitotic figures per 10 high-powered fields. The tumor contained thin-wall vessels in the stroma and hyaline degenerated fibrous stroma was observed in the focal area (Figure 1D). Necrosis was absent.

Immunobiologically, the tumor diffusely expressed estrogen receptor (ER), progesterone receptor (PR), AE1/AE3 (Figure 2A), desmin (Figure 2B), Wilm's tumor1 (WT-1; Figure 2C), CD56, and CD99. Epithelial membrane antigen (EMA) and $\beta$-catenin were focally membrane positive. Calretinin, $a$-inhibin, FOXL2, stromal factor 1 (SF1), CD10, smooth muscle actin, h-Caldesmon, paired box gene 8, cytokeratin 7, cyclin D1, high-mobility group box 45 (HBM45), and Melan-A (A103) were all negative. The Ki67 index was 5\%. UTROSCT was diagnosed based on the morphological features and immunophenotype. The patient did not receive any chemotherapy or radiotherapy.

Thirty months later, the tumor recurred with a $7.0 \times 6.0 \times 5.0-\mathrm{cm}$ pelvic nodule. The patient underwent a pelvic mass resection. Morphologically, the recurrent tumor was similar to the original specimen. Epithelioid or short spindle tumor cells were arranged in nested (80\%; Figure 1E), cordlike (15\%; Figure 1F), and focal whorl ( $5 \%$; Figure $1 \mathrm{G}$ ) patterns. Cystic changes were observed in the focal area (Figure 1F). The immunophenotype was virtually identical to that of the original neoplasm.

Molecularly, the break apart fluorescence in situ hybridization (FISH) [7] for NCOA2 (Abbott Molecular, Abbott Park, IL, USA) revealed that more than 50\% of the recurrent tumor cells showed a separated red and green signal probe that was consistent with a chromosome translocation involving the $N C O A 2$ gene (Figure 2D). RNA sequencing (NextSeq Reagent Kit, Illumina, Inc., San Diego, CA, USA) using RNA from formalin-fixed, paraffin-embedded specimens [8] revealed an in-frame gene fusion between GREB1 exon 3 (NM_014668.3) and NCOA2 exon (NM_006540.3) (t (2;8)(p25;q13) (Figure 3). Slides of primary and recurrent neoplasm samples were reviewed by two gynecological pathologists (BC and HJG), and the diagnosis of UTROSCT was confirmed. Following pelvic mass resection, the patient received chemotherapy with three cycles of paclitaxel liposome and carboplatin and showed no evidence of lesions for 5 months after surgery in the last follow-up.

\section{Discussion}


UTROSCTs are rare neoplasms of unclear histogenesis that are typically located in the uterine corpus and rarely in the endocervix. The morphological features of UTROSCT overlap with those of ovarian sex-cord tumors. The World Health Organization classifies UTROSCTs in the category of "endometrial stromal and related tumors" [9]. However, genetically, these tumors are separate entities that harbor different molecular abnormalities and have different prognoses. The majority of low-grade endometrial stromal sarcomas (LG-ESSs) harbor a fusion gene, most commonly involving JAZF1, SUZ12, and/or PHF1 genes, i.e., JAZF1-SUZ12 fusion (80\%), JAZF1-PHF1 fusion (6\%), or EPC1-PHF1 fusion (4\%) [10-12]. The rare fusions of MEAF6-PHF1 (3\%) and MBTD1-CXORF67 (2\%) have also been reported in LG-ESSs [12-14]. In contrast, high-grade endometrial stromal sarcomas (HG-ESSs) have been found to harbor $Y W H A E-N U T M 2 A / B$ or ZC3H7B-BCOR fusion genes and to exhibit more aggressive behavior [15-18].

Recently, characteristic fusions involving ESR1 and GREB1, which are key factors in sex hormone pathways, were identified in 31 cases of UTROSCT; these included ESR1-NCOA3 ( $\mathrm{N}=15)$, ESR1-NCOA2 $(\mathrm{N}=5)$, GREB1-NCOA1 $(\mathrm{N}=5)$, GREB1-NCOA2 $(\mathrm{N}=4)$, GREB1-CTNNB1 ( $\mathrm{N}=1)$, GREB1-NR4A3 ( $\mathrm{N}=1)$, GREB1-SS18 $(\mathrm{N}=1)$, and NCOA2 rearrangement with an unknown partner gene $(\mathrm{N}=1)[1-4,19]$. Although most cases exhibit benign behavior, UTROSCT is considered to have uncertain malignant potential owing to its low rate of recurrence (5.9\%) [5]. However, a recent large series reported that up to $23.5 \%$ of UTROSCT cases develop extra-uterine recurrence [6]. The intrinsic molecular mechanisms of UTROSCT that underly its different clinical behaviors are still unclear. In the current case of recurrent UTROSCT in a postmenopausal woman with GREB1-NCOA2 fusion gene, it is possible that the GREB1 rearrangement contributed to the aggressive behavior.

The clinical symptoms of UTROSCT are not specific. Typically, UTROSCTs are well circumscribed but unencapsulated. True myometrium invasion is uncommon but can be present in some cases and may be correlated with aggressive behavior. The tumor cells are organized in sheets, nests, trabeculae, or hollow or solid tubules with a repetitive pattern of cordlike or tubular growth; more rarely, the cells will have retiform or glomeruloid appearance or papillae and a solid pattern predominance. Neoplastic cells are small, round, ovoid to spindle with monotonous nuclei, inconspicuous or small to medium with distinct nucleoli, and occasionally have vascular invasion, heterologous elements, or necrosis. UTROSCTs exhibit a co-expression of epithelial, smooth muscle, sexcord markers, and steroid receptors.

GREB1-rearranged uterine tumors often show prominently fascicular spindle cells or trabecular/cord-like arranged epithelioid cells and an inconspicuous immunophenotype of sex-cord differentiation [4]. Similarly, our case showed predominantly diffuse sheets of short spindle cells and nests of epithelioid cells in the primary tumor. Immunohistochemically, the tumor cells were positive for epithelial markers (AE1/AE3, EMA), a smooth muscle marker (desmin), and less specific sex-cord markers (CD56, WT-1, CD99), but negative for relatively specific sex-cord markers (a-inhibin, calretinin, FOXL2, and SF1). Although without well-formed tubules or retiform structure, the extensive sex-cord-like patterns in our case, including nests and trabeculae/cords, strongly suggested the diagnosis of UTROSCT rather than other mesenchymal tumors, such as LG-ESS with sex-cord differentiation. The details of five cases of GREB1-rearranged UTROSCT reported previously [1] contrasted with the cases described by Cheng-Han et al. and with the current case because all five cases in that series had prominent sex-cord differentiation and were positive for a-inhibin and/or calretinin immunostaining. Whether GREB1-rearranged UTROSCT had specific morphological and immunohistochemical features should be investigated further when additional cases have been reported.

Regarding prognosis, GREB1-rearranged tumors tended to occur in significantly older women than did UTROSCT with ESR1 fusions (51-70 years old, median: 65 years versus 34-55 years, median 47 years) [4]; moreover, GREB1-rearranged tumors tended to be larger and more mitotically active (0-14 versus $0-1$ ) and appeared to behave more aggressively. The current case was a 57-year-old postmenopausal woman with a 10.0-cm uterine mass and three mitotic figures per 10 high-powered fields in the primary and recurrent tumors. The tumor cells were determined by FISH to have NCOA2 rearrangement and by RNA sequencing to harbor a GREB1-NCOA2 fusion. These pathological and clinical features of our case were consistent with the cases described by Lee et al. and provided evidence for the recurrent aggressive behaviors of GREB1-rearranged uterine tumors.

Seven cases of GREB1-rearranged uterine tumors were previously summarized (4); of these, six cases had follow-up information, and two cases developed pelvic dissemination and/or lung metastasis with more than 1 year of follow-up. A recent report [1] described 26 cases of UTROSCT with NCOA1-3 rearrangement. Of these, five cases were GREB1-rearranged UTROSCT. The only recurrent case in that report harbored GREB1-NCOA2 fusion. The current case is the fourth known recurrent case with GREB1 rearrangement in the literature. The tumor recurred 30 months after a total hysterectomy with bilateral salpingooophorectomy.

To date, 12 cases of GREB1-rearranged uterine sarcoma have been reported in the English literature [1-4, 19]; the current case is the 13th known case. The clinicopathological features of all known GREB1-rearranged tumors, including our case, are summarized in Table 1. The mean age of the patients was 64.8 years (range, 51-74 years). Follow-up information was available for nine cases $(69.3 \%, 9 / 13)$, with a mean follow-up interval of 23.7 months (range, 0.75-66 months). Of these nice cases, four cases were recurrent or metastasized cases (44.4\%). Of these, three tumors recurred in the pelvis (at 17,30 , and 66 months) and one metastasized to the lung after the initial diagnosis (at 24 and 132 months). The other five patients were alive without evidence of disease at the last follow-up (range, $0.75-54.3$ months). The average tumor size was $9.1 \mathrm{~cm}$ (range, $4.2-14.9 \mathrm{~cm}$ ). Microscopically, the tumor growth pattern of most tumors (10/12, 83.3\%) was infiltrative growth (including three focal invasion; cases 2, 3, and 4), and two were well demarcated. Mitotic figures ranged from $0-$ 14 per 10 high-powered field ( $2 \mathrm{~mm}^{2}$; mean: 3.6). Lymphovascular invasion and necrosis were each present in two cases $(2 / 12,16.7 \%$ and $2 / 7,28.6 \%$, respectively). 
Table 1

Clinicopathologic features of GREB1-rearranged uterine sarcoma

\begin{tabular}{|c|c|c|c|c|c|c|c|c|c|c|c|}
\hline $\begin{array}{l}\text { Case } \\
\text { number }\end{array}$ & $\begin{array}{l}\text { Age } \\
\text { Range } \\
\text { (years) }\end{array}$ & $\begin{array}{l}\text { Tumor } \\
\text { size } \\
(\mathrm{cm})\end{array}$ & $\begin{array}{l}\text { Microscopic } \\
\text { tumor } \\
\text { margins }\end{array}$ & Tumor architecture & Cytomorphology & $\begin{array}{l}\text { Mitosis } \\
\text { (per } 10 \\
\text { HPF) }\end{array}$ & LVI§ & Necrosis & $\begin{array}{l}\text { Fusion } \\
\text { gene }\end{array}$ & $\begin{array}{l}\text { Pathology } \\
\text { diagnosis }\end{array}$ & Stage \\
\hline \multicolumn{12}{|l|}{$\begin{array}{l}\text { Cheng- } \\
\text { Han et } \\
\text { al } \\
(2019)\end{array}$} \\
\hline 1 & $56-60$ & 10.0 & $\begin{array}{l}\text { Well } \\
\text { demarcated }\end{array}$ & $\begin{array}{l}\text { Diffuse, fascicular, } \\
\text { trabecular/corded }\end{array}$ & $\begin{array}{l}\text { Epithelioid and } \\
\text { spindle, } \\
\text { occasional } \\
\text { rhabdoid } \\
\text { features. }\end{array}$ & 8 & - & - & $\begin{array}{l}\text { GREB1- } \\
\text { NCOA2 }\end{array}$ & UUS-U\# & IB \\
\hline 2 & $55-60$ & 14.9 & $\begin{array}{l}\text { Generally } \\
\text { well- } \\
\text { defined; rare } \\
\text { foci of } \\
\text { tongue-like } \\
\text { protrusions }\end{array}$ & $\begin{array}{l}\text { Diffuse, } \\
\text { trabecular/corded, } \\
\text { fascicular }\end{array}$ & $\begin{array}{l}\text { Epithelioid and } \\
\text { spindle }\end{array}$ & 14 & + & + & $\begin{array}{l}\text { GREB1- } \\
\text { NR4A3 }\end{array}$ & $\begin{array}{l}\text { GREB1- } \\
\text { regrranged } \\
\text { sarcoma }\end{array}$ & IB \\
\hline 3 & $65-70$ & 8.5 & $\begin{array}{l}\text { Myometrial } \\
\text { delicate cell } \\
\text { cords } \\
\text { invasion }\end{array}$ & $\begin{array}{l}\text { Trabecular/corded, } \\
\text { diffuse, nested }\end{array}$ & Epithelioid & 7 & - & - & $\begin{array}{l}\text { GREB1- } \\
\text { SS18 }\end{array}$ & $\begin{array}{l}\text { Atypical } \\
\text { mesenchymal } \\
\text { tumor }\end{array}$ & IB \\
\hline 4 & $60-65$ & 4.2 & $\begin{array}{l}\text { Rare foci } \\
\text { tongue-like } \\
\text { protrusion }\end{array}$ & $\begin{array}{l}\text { Trabecular/corded, } \\
\text { diffuse, nested, } \\
\text { fascicular; } \\
\text { multifocal } \\
\text { tubular/retiform } \\
\text { structures }\end{array}$ & $\begin{array}{l}\text { Epithelioid and } \\
\text { spindle, rare } \\
\text { lipid-laden cells } \\
\text { and Leydig-like } \\
\text { cells }\end{array}$ & 2 & - & - & $\begin{array}{l}\text { GREB1- } \\
\text { NCOA1 }\end{array}$ & $\begin{array}{l}\text { GREB1- } \\
\text { regrranged } \\
\text { sarcoma }\end{array}$ & IA \\
\hline \multicolumn{12}{|l|}{$\begin{array}{l}\text { Croce et } \\
\text { al } \\
(2019)\end{array}$} \\
\hline 5 & $65-70$ & 10.0 & $\begin{array}{l}\text { Relatively } \\
\text { well } \\
\text { demarcated }\end{array}$ & $\begin{array}{l}\text { Diffuse, nested, } \\
\text { trabecular }\end{array}$ & $\begin{array}{l}\text { Epithelioid, focal } \\
\text { rhabdoid } \\
\text { appearance }\end{array}$ & 1 & - & NA & $\begin{array}{l}\text { GREB1- } \\
\text { CTNNB1 }\end{array}$ & UTROSCT & IB \\
\hline \multicolumn{12}{|l|}{$\begin{array}{l}\text { Brunetti } \\
\text { et al } \\
\text { (2018) }\end{array}$} \\
\hline 6 & $50-55$ & 6.5 & Infiltrative & $\begin{array}{l}\text { Primary tumor: } \\
\text { diffuse fascicular; } \\
\text { recurrent tumor: } \\
\text { solid growth } \\
\text { pattern }\end{array}$ & $\begin{array}{l}\text { Primary tumor: } \\
\text { spindle and } \\
\text { polygonal cells } \\
\text { displaying } \\
\text { pronounced } \\
\text { atypia; } \\
\text { Recurrent tumor: } \\
\text { predominantly } \\
\text { epithelioid }\end{array}$ & $\begin{array}{l}\text { multiple } \\
\text { mitotic } \\
\text { figures* }\end{array}$ & + & + & $\begin{array}{l}\text { GREB1- } \\
\text { NCOA2 }\end{array}$ & $\begin{array}{l}\text { High-grade } \\
\text { endometrial } \\
\text { sarcoma[ } \\
\text { sarcoma, not } \\
\text { otherwise } \\
\text { classifiable }\end{array}$ & IB \\
\hline \multicolumn{12}{|l|}{$\begin{array}{l}\text { Dickson } \\
\text { et al } \\
\text { (2019) }\end{array}$} \\
\hline 7 & $65-70$ & $\begin{array}{l}0.7- \\
3.3^{*}\end{array}$ & NA & $\begin{array}{l}\text { Fascicles, focal } \\
\text { tubular pattern }\end{array}$ & $\begin{array}{l}\text { Spindle and } \\
\text { epithelioid }\end{array}$ & $0-1$ & NA & - & $\begin{array}{l}\text { GREB1- } \\
\text { NCOA2 }\end{array}$ & UTROSCT & 1 \\
\hline \multicolumn{12}{|l|}{$\begin{array}{l}\text { Goebel } \\
\text { et al } \\
(2019)\end{array}$} \\
\hline 8 & $70-75$ & 6.2 & Infiltrative & Nested, corded & $\begin{array}{l}\text { Spindle and } \\
\text { epithelioid }\end{array}$ & 1 & - & NA & $\begin{array}{l}\text { GREB1- } \\
\text { NCOA1 }\end{array}$ & UTROSCT & NA \\
\hline 9 & $70-75$ & NA & Infiltrative & $\begin{array}{l}\text { Sertoliform, } \\
\text { retiform }\end{array}$ & $\begin{array}{l}\text { Spindle and } \\
\text { epithelioid }\end{array}$ & $<1$ & - & NA & $\begin{array}{l}\text { GREB1- } \\
\text { NCOA1 }\end{array}$ & UTROSCT & NA \\
\hline 10 & $70-75$ & 13.0 & Infiltrative & $\begin{array}{l}\text { Corded, trabecular, } \\
\text { sertoliform, } \\
\text { retiform }\end{array}$ & $\begin{array}{l}\text { Spindle and } \\
\text { epithelioid }\end{array}$ & 1 & - & NA & $\begin{array}{l}\text { GREB1- } \\
\text { NCOA2 }\end{array}$ & UTROSCT & NA \\
\hline 11 & $70-75$ & $\begin{array}{l}\text { at } \\
\text { least } \\
2.5\end{array}$ & Infiltrative & Sertoliform & $\begin{array}{l}\text { Spindle and } \\
\text { epithelioid }\end{array}$ & 3 & - & NA & $\begin{array}{l}\text { GREB1- } \\
\text { NCOA1 }\end{array}$ & UTROSCT & NA \\
\hline 12 & $60-65$ & 8.0 & Infiltrative & $\begin{array}{l}\text { Nested, corded, } \\
\text { whorled }\end{array}$ & $\begin{array}{l}\text { Spindle and } \\
\text { epithelioid }\end{array}$ & 2 & - & NA & $\begin{array}{l}\text { GREB1- } \\
\text { NCOA1 }\end{array}$ & UTROSCT & NA \\
\hline
\end{tabular}




\begin{tabular}{|c|c|c|c|c|c|c|c|c|c|c|c|}
\hline $\begin{array}{l}\text { Case } \\
\text { number }\end{array}$ & $\begin{array}{l}\text { Age } \\
\text { Range } \\
\text { (years) }\end{array}$ & $\begin{array}{l}\text { Tumor } \\
\text { size } \\
(\mathrm{cm})\end{array}$ & $\begin{array}{l}\text { Microscopic } \\
\text { tumor } \\
\text { margins }\end{array}$ & Tumor architecture & Cytomorphology & $\begin{array}{l}\text { Mitosis } \\
\text { (per 10 } \\
\text { HPF) }\end{array}$ & LVI§ & Necrosis & $\begin{array}{l}\text { Fusion } \\
\text { gene }\end{array}$ & $\begin{array}{l}\text { Pathology } \\
\text { diagnosis }\end{array}$ & Stage \\
\hline \multicolumn{12}{|l|}{$\begin{array}{l}\text { Present } \\
\text { case }\end{array}$} \\
\hline 13 & $55-60$ & 10.0 & Infiltrative & $\begin{array}{l}\text { Diffuse, nested, } \\
\text { trabecular/corded, } \\
\text { and focal } \\
\text { anastomotic } \\
\text { glandular }\end{array}$ & $\begin{array}{l}\text { Spindle and } \\
\text { epithelioid }\end{array}$ & 3 & - & - & $\begin{array}{l}\text { GREB1- } \\
\text { NCOA2 }\end{array}$ & UTROSCT & IB \\
\hline
\end{tabular}

Of these 13 cases of GREB1-rearranged uterine tumors, eight cases (including our case) had a definite pathological diagnosis of UTROSCT, with typical morphological and/or immunohistochemical features. Five cases were diagnosed as undifferentiated uterine sarcoma with nuclear uniformity, GREB1rearranged sarcoma, atypical mesenchymal tumor, and sarcoma, not otherwise classifiable (cases 1, 2, 3, 4, and 6, respectively) (Table 1). Of these five cases, three cases (cases 2, 3, and 4) showed a focal trabeculae/cord pattern, which is an important morphologic clue for the diagnosis of UTROSCT. However, two cases (cases 1 and 6) showed morphologic features of high-grade sarcoma, predominantly composed of diffuse sheets of epithelioid, spindle, or polygonal cells and without conspicuous sex-cord-like patterns or the sex-cord-like differentiation immunophenotype. This could indicate that molecular detection, including the GREB1 rearrangement, should be used with cases of HG-ESS, undifferentiated sarcoma, and other high-grade sarcomas, which cannot be classified as any specific uterine sarcoma subtype, to clarify whether they are poorly differentiated UTROSCT or a distinct sarcoma subtype.

A systematic review by Blake et al. and a large case series by Moore et al. reported GREB 1-rearranged uterine tumor recurrence rates of 5.9\% and 23.5\%, respectively; however, neither of these reports addressed the genetic findings $[5,6]$. According to Moore et al,, cases of UTROSCT that behaved in a malignant manner were associated with older age, larger tumor size, and higher mitotic activity [6]. These aggressive and/or older patients included in the study by Moore et al. may have had a high frequency of GREB1 rearrangement; however, the study did not address the molecular events. Additionally, the relatively higher recurrence rate in the series by Moore et al. may in part reflect a referral bias related to consultation cases in their series, which more often presented with unusual clinical behavior. Although the case number is limited, the higher recurrence rate of GREB1-rearranged uterine tumors could indicate that this type has a greater tendency towards aggressive behavior. Additional cases are needed to clarify the correlation between morphologic features, prognosis, and intrinsic molecular events.

Due to the rarity of this type of tumor, there is no well-established treatment protocol for UTROSCT, as there are limited data available for guiding clinical management. The initial clinical treatment strategies for UTROSCT include tumor resection, total abdominal hysterectomy alone, or total abdominal hysterectomy with bilateral adnexectomy, in consideration of patient age and parity. Recurrent cases are managed by repeated surgical procedures, and no evidence supports the usefulness of chemotherapy for recurrent cases [6]. Additional investigation of the correlation between specific molecular events and prognostic significance is essential for the development of therapeutic strategies, especially for tumors with aggressive behavior.

GREB1 encodes growth regulation by estrogen in breast cancer 1, a protein transcriptionally driven by estrogen-bound ER. Furthermore, GREB1 is a key factor of the canonical estrogen/ER signaling pathway [20]. Functionally, GREB1 is one of the most important tamoxifen/RU486-suppressed ER pathway downstream effectors, which indicates that GREBrearranged tumors may respond to tamoxifen and RU486 [4, 21]. ESR1 encodes estrogen receptor 1 , a ligand-dependent transcription factor. Binding with estrogen, ESR1 is not only essential for sexual development, reproductive function, and bone formation but is also involved in pathologic processes, including breast cancer, endometrial cancer, and osteoporosis. Several mutations in the ligand-binding domain of ESR1 have been found to be correlated with resistance to hormone therapy in ER-positive breast cancer [22, 23]. ESR1-rearranged UTROSCT may not be susceptible to an estrogen blockade because the ER ligand-binding domain is lost in fusions involving ESR1 (4). The partner genes of GREB1-or ESR1rearranged UTROSCT, including NCOA1-3, NRAA3, SS18, and CTNNB1, all encode transcription factors, and the basic function of each, as reported previously [4], is listed in Table 2. Five cases of UTROSCT that are suspected to be related to tamoxifen treatment have been reported [24]; however, the molecular features of these tamoxifen treatment-related cases were not determined. The complicated mechanism underlying chromosome translocation involving different functional genes, prognosis, and response to tamoxifen is still unclear. Although hormonal treatment has not yet been explored for UTROSCT, such in vitro and in vivo research may be necessary.

Table 2

Function of partner genes related to GREB1 rearrangement

\begin{tabular}{|c|c|c|}
\hline Gene & Encoded Protein & Basic Function \\
\hline CTNNB1 & $\beta$-Catenin & $\begin{array}{l}\text { Crucial transcriptional factor in Wingless-Int (Wnt)/ } \beta \text {-catenin signaling pathway; transcriptional coactivator for T-cell } \\
\text { factor/lymphoid enhancer factor (TCF), and with its transactivation domain, activates transcription initiation, histone } \\
\text { methyltransferases, chromatin modification, and transcription facilitation }\end{array}$ \\
\hline $\begin{array}{l}\text { NCOA1- } \\
3\end{array}$ & $\begin{array}{l}\text { Nuclear Receptor } \\
\text { Coactivator } 1-3\end{array}$ & Transcription factors: coactivate nuclear hormone receptors and mediate steroid/sex-hormone receptor pathways \\
\hline NR4A3 & $\begin{array}{l}\text { Nuclear Receptor } \\
\text { Subfamily } 4 \\
\text { Group A Member } \\
3\end{array}$ & $\begin{array}{l}\text { Transcription factor: transcriptional activator of the steroid/thyroid hormone nuclear receptor family, with a role in } \\
\text { regulating proliferation, survival, and differentiation }\end{array}$ \\
\hline SS18 & SS18 (or SSXT) & Transcription factor: transcriptional coactivator and a component of the SWI/SNF chromatin-remodeling complex \\
\hline
\end{tabular}


In conclusion, we reported a case of recurrent UTROSCT in a 57-year-old woman with the GREB1-NCOA2 fusion gene. This case provides further evidence that uterine tumors with GREB1-rearrangement may have a high recurrence risk. Further studies are necessary to elucidate the clinical features of UTROSCT, especially the prognosis, potential treatments, and the range of possible molecular events.

\section{List Of Abbreviations}

UTROSCT, uterine tumors resembling ovarian sex-cord tumor; ESR1, estrogen receptor 1; NCOA, nuclear receptor coactivator; GREB1, growth regulation by estrogen in breast cancer 1; CTNNB1, catenin beta 1; NR4A3, nuclear receptor subfamily 4 group A member 3; SS18, synovial sarcoma translocation, chromosome 18; ER, estrogen receptor; PR, progesterone receptor; WT-1, Wilm's tumor-1; EMA, epithelial membrane antigen; SF1, stromal factor 1; FISH, fluorescence in situ hybridization; LG-ESS, low-grade endometrial stromal sarcoma; HG-ESS, high-grade endometrial stromal sarcoma

\section{Declarations}

\section{Ethics approval and consent to participate}

The authors of this manuscript obtained patient consent for publication of clinical data and images. The patient's details were anonymized, and the patient signed a consent form for publication. Due to the retrospective and noninterventional nature of the study, permission by the local ethics committee was not required.

\section{Consent for publication}

The authors of this manuscript obtained patient consent for publication of clinical data and images. The patient's details were anonymized, and the patient signed an consent form for publication.

\section{Availability of data and materials}

Not applicable

\section{Competing interests}

The authors declare that they have no conflict of interest

\section{Funding}

The authors declare that no funding was received for this study.

\section{Authors' contributions}

BC designed the study, collected the patient's data, provided the figures, and wrote the original manuscript. BQ and YQ performed the FISH and RNA sequencing experiment. LL provided the immunohistochemical figures. $\mathrm{GH}$ made the pathologic diagnosis of the primary tumor. The final version of the manuscript was read and approved by all authors.

\section{Acknowledgements}

We would like to thank Editage (www.editage.com) for English language editing.

\section{References}

1. Goebel EA, Hernandez Bonilla S, Dong F, Dickson BC, Hoang LN, Hardisson D, et al. Uterine Tumor Resembling Ovarian Sex Cord Tumor (UTROSCT): A Morphologic and Molecular Study of 26 Cases Confirms Recurrent NCOA1-3 Rearrangement. The American journal of surgical pathology. $2020 ; 44: 30-42$.

2. Dickson BC, Childs TJ, Colgan TJ, Sung YS, Swanson D, Zhang L, et al. Uterine Tumor Resembling Ovarian Sex Cord Tumor: A Distinct Entity Characterized by Recurrent NCOA2/3 Gene Fusions. The American journal of surgical pathology. 2019;43:178-186.

3. Croce S, Lesluyes T, Delespaul L, Bonhomme B, Perot G, Velasco V, et al. GREB1-CTNNB1 fusion transcript detected by RNA-sequencing in a uterine tumor resembling ovarian sex cord tumor (UTROSCT): A novel CTNNB1 rearrangement. Genes, chromosomes \& cancer. 2019;58:155-163.

4. Lee CH, Kao YC, Lee WR, Hsiao YW, Lu TP, Chu CY, et al. Clinicopathologic Characterization of GREB1-rearranged Uterine Sarcomas With Variable Sex-Cord Differentiation. The American journal of surgical pathology. 2019;43:928-942.

5. Blake EA, Sheridan TB, Wang KL, Takiuchi T, Kodama M, Sawada K, et al. Clinical characteristics and outcomes of uterine tumors resembling ovarian sexcord tumors (UTROSCT): a systematic review of literature. European journal of obstetrics, gynecology, and reproductive biology. 2014;181:163-170.

6. Moore M, McCluggage WG. Uterine tumour resembling ovarian sex cord tumour: first report of a large series with follow-up. Histopathology. 2017;71:751759.

7. Chang B, Yu L, Guo WW, Sheng WQ, Wang L, Lao I, et al. Malignant Gastrointestinal Neuroectodermal Tumor: Clinicopathologic, Immunohistochemical, and Molecular Analysis of 19 Cases. The American journal of surgical pathology. 2020;44:456-466.

8. Inamura K, Kobayashi M, Nagano H, Sugiura Y, Ogawa M, Masuda H, et al. A novel fusion of HNRNPA1-ALK in inflammatory myofibroblastic tumor of urinary bladder. Human pathology. 2017;69:96-100. 
9. Oliva E, Carcangiu, M.L., Carinelli S.G., Loening T. Longacre T.A., Nucci M.R.. et al, Tumor of the uterine corpus, mesenchymal tumors. In: Kurman RJ, Carcangiu, M.L., Herrington, C.S., Young, R.H., etitors. WHO Classification of Tumors of Female Reproductive Organs. Fourth Edition. Lyon, Academic; 2014; p.145.

10. Dickson BC, Lum A, Swanson D, Bernardini MQ, Colgan TJ, Shaw PA, et al. Novel EPC1 gene fusions in endometrial stromal sarcoma. Genes, chromosomes \& cancer. 2018;57:598-603.

11. Koontz JI, Soreng AL, Nucci M, Kuo FC, Pauwels P, van Den Berghe $\mathrm{H}$, et al. Frequent fusion of the JAZF1 and JJAZ1 genes in endometrial stromal tumors. Proceedings of the National Academy of Sciences of the United States of America. 2001; 98:6348-6353.

12. Lee $\mathrm{CH}$, Nucci MR. Endometrial stromal sarcoma--the new genetic paradigm. Histopathology. 2015; 67:1-19.

13. Micci F, Gorunova L, Gatius S, Matias-Guiu X, Davidson B, Heim S, et al. MEAF6/PHF1 is a recurrent gene fusion in endometrial stromal sarcoma. Cancer letters. 2014;347:75-78.

14. Dewaele B, Przybyl J, Quattrone A, Finalet Ferreiro J, Vanspauwen V, Geerdens E, et al. Identification of a novel, recurrent MBTD1-CXorf67 fusion in lowgrade endometrial stromal sarcoma. International journal of cancer. 2014;134:1112-1122.

15. Conklin CM, Longacre TA. Endometrial stromal tumors: the new WHO classification. Advances in anatomic pathology. 2014;21:383-393.

16. Hoang LN, Aneja A, Conlon N, Delair DF, Middha S, Benayed R, et al. Novel High-grade Endometrial Stromal Sarcoma: A Morphologic Mimicker of Myxoid Leiomyosarcoma. The American journal of surgical pathology. 2017;41:12-24.

17. McCluggage WG, Lee CH. YWHAE-NUTM2A/B Translocated High-grade Endometrial Stromal Sarcoma Commonly Expresses CD56 and CD99. International journal of gynecological pathology : official journal of the International Society of Gynecological Pathologists. 2019; 38:528-532.

18. Croce S, Hostein I, Ribeiro A, Garbay D, Velasco V, Stoeckle E, et al. YWHAE rearrangement identified by FISH and RT-PCR in endometrial stromal sarcomas: genetic and pathological correlations. Modern pathology : an official journal of the United States and Canadian Academy of Pathology, Inc. 2013;26:13901400 .

19. Brunetti M, Panagopoulos I, Gorunova L, Davidson B, Heim S, Micci F. RNA-sequencing identifies novel GREB1-NCOA2 fusion gene in a uterine sarcoma with the chromosomal translocation $t(2 ; 8)(p 25 ; q 13)$. Genes, chromosomes \& cancer. 2018; 57:176-181.

20. Mohammed H, D'Santos C, Serandour AA, Ali HR, Brown GD, Atkins A, et al. Endogenous purification reveals GREB1 as a key estrogen receptor regulatory factor. Cell reports. 2013;3:342-349.

21. Cheng M, Michalski S, Kommagani R. Role for Growth Regulation by Estrogen in Breast Cancer 1 (GREB1) in Hormone-Dependent Cancers. International journal of molecular sciences. 2018:19:2543.

22. Lopez-Knowles E, Pearson A, Schuster G, Gellert P, Ribas R, Yeo B, et al. Molecular characterisation of aromatase inhibitor-resistant advanced breast cancer: the phenotypic effect of ESR1 mutations. British journal of cancer. 2019; 120:247-255.

23. Schiavon G, Hrebien S, Garcia-Murillas I, Cutts RJ, Pearson A, Tarazona N, et al. Analysis of ESR1 mutation in circulating tumor DNA demonstrates evolution during therapy for metastatic breast cancer. Science translational medicine. 2015;7:313ra182.

24. Segala D, Gobbo S, Pesci A, Martignoni G, Santoro A, Angelico G, et al. Tamoxifen related Uterine Tumor Resembling Ovarian Sex Cord Tumor (UTROSCT): A case report and literature review of this possible association. Pathology, research and practice. 2019; 215:1089-1092.

\section{Figures}



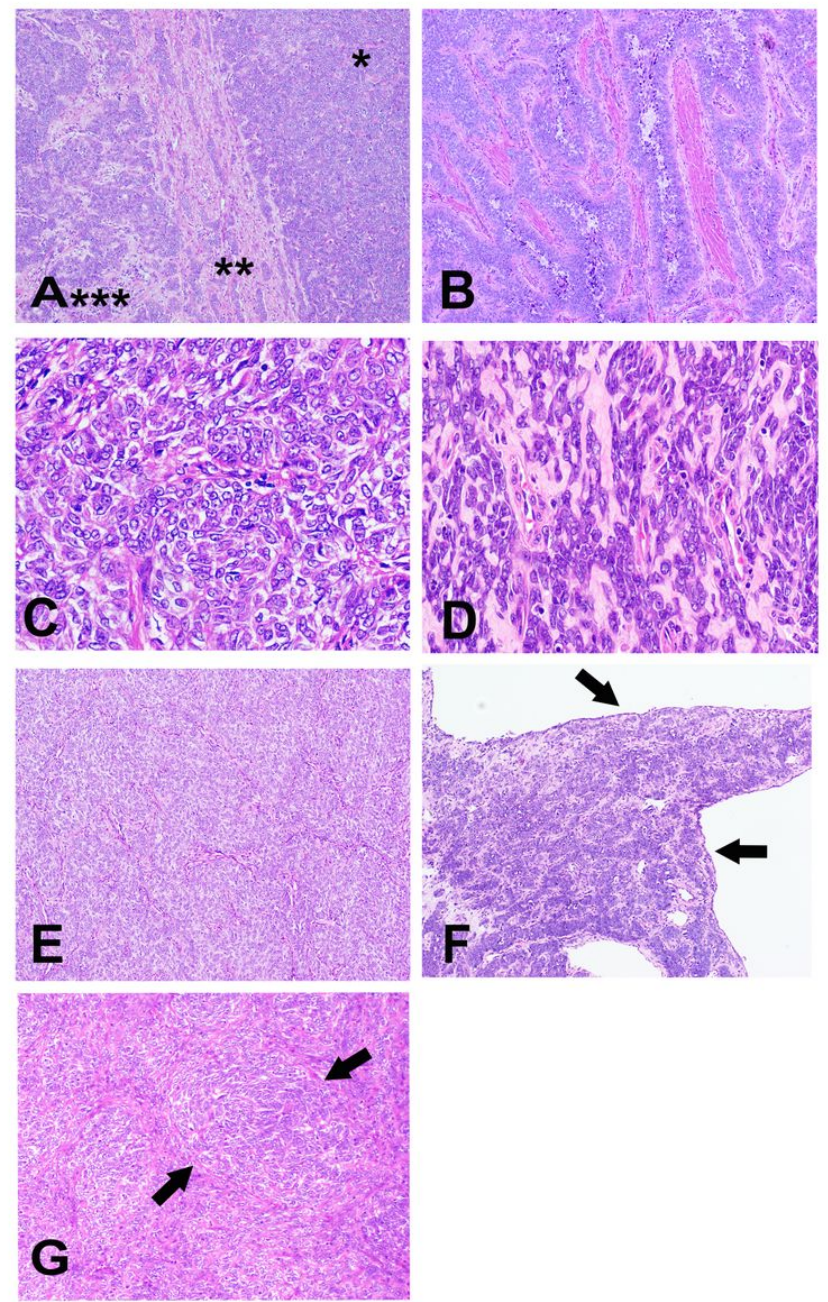

\section{Figure 1}

Histological and cytological features of UTROSCT. (A) The tumor contained diffuse sheets $\left({ }^{*}\right)$, trabecular/cords $\left({ }^{\star *}\right)$, and nested growth patterns $\left({ }^{\star \star \star}\right)$ (hematoxylin and eosin stain, $\times 100)$. (B) Focal anastomotic glandular growth pattern $(\times 200)$. (C) The tumor was composed of short spindle and epithelioid cells with scant eosinophilic cytoplasm and round to ovoid bland vesicular nuclei with small or medium prominent nucleoli ( $\times 400)$. (D) The tumor contained thin-wall vessels in the stroma, and hyaline degenerated fibrous stroma was observed in the focal area ( $\times 400)$. (E) The recurrent tumor was composed of short spindle and epithelioid tumor cells arranged in inconspicuous nodules with few stroma $(\times 200)$. (F) Cordlike pattern and the tumor with cystic changes ( $\times 100)$. (G) Focal whorls were present in the recurrent tumor $(\times 200)$. 

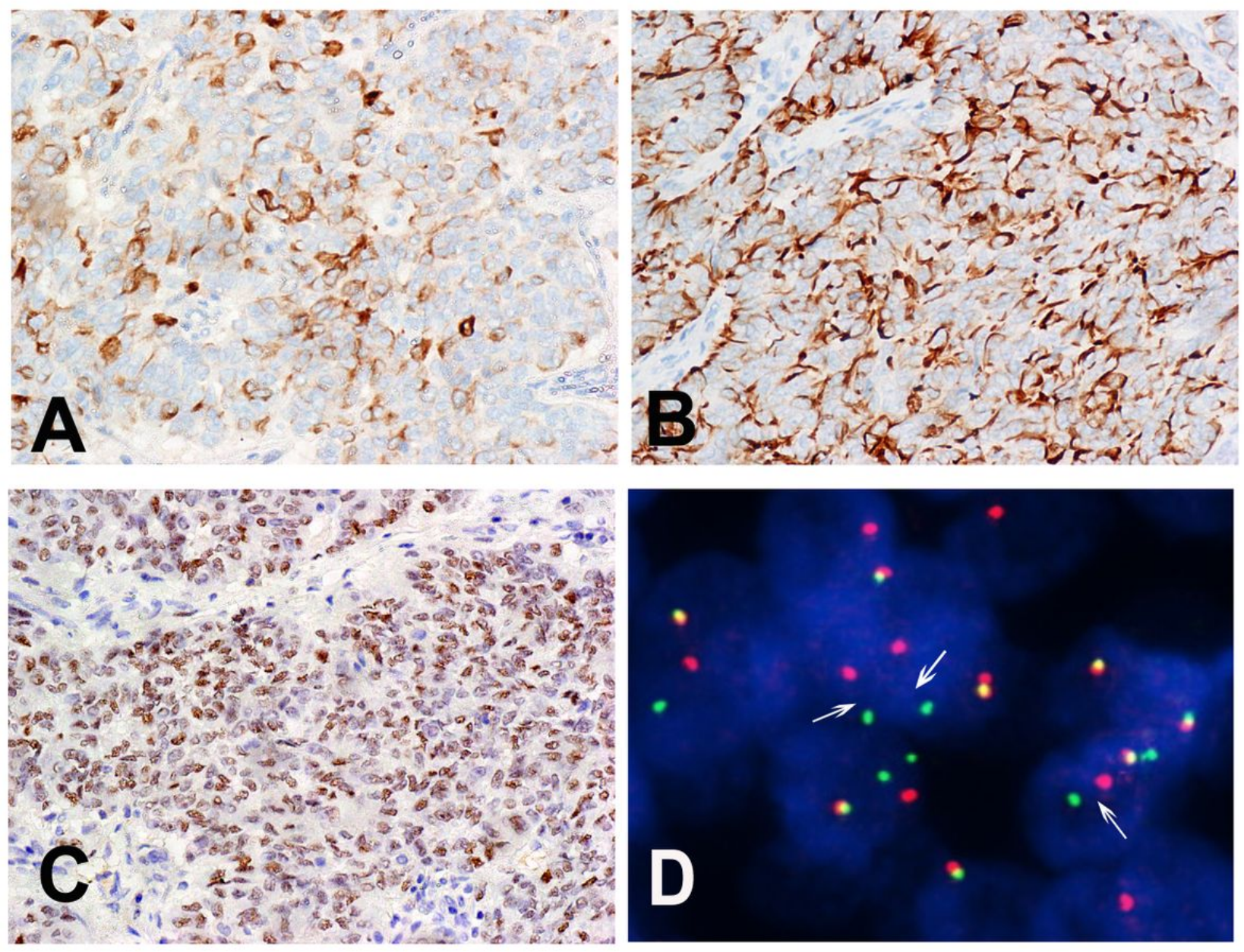

Figure 2

Immunohistological and molecular features of the UTROSCT. (A) AE1/AE3 was positive in the UTROSCT ( $\times 400)$. (B) Neoplastic cells expressed desmin in the cytoplasm $(\times 400)$. (C) Neoplastic cells expressed WT1 in the nuclei $(\times 200)$. (D) FISH studies. NCOA2 showing split-apart red and green signals in the tumor cells

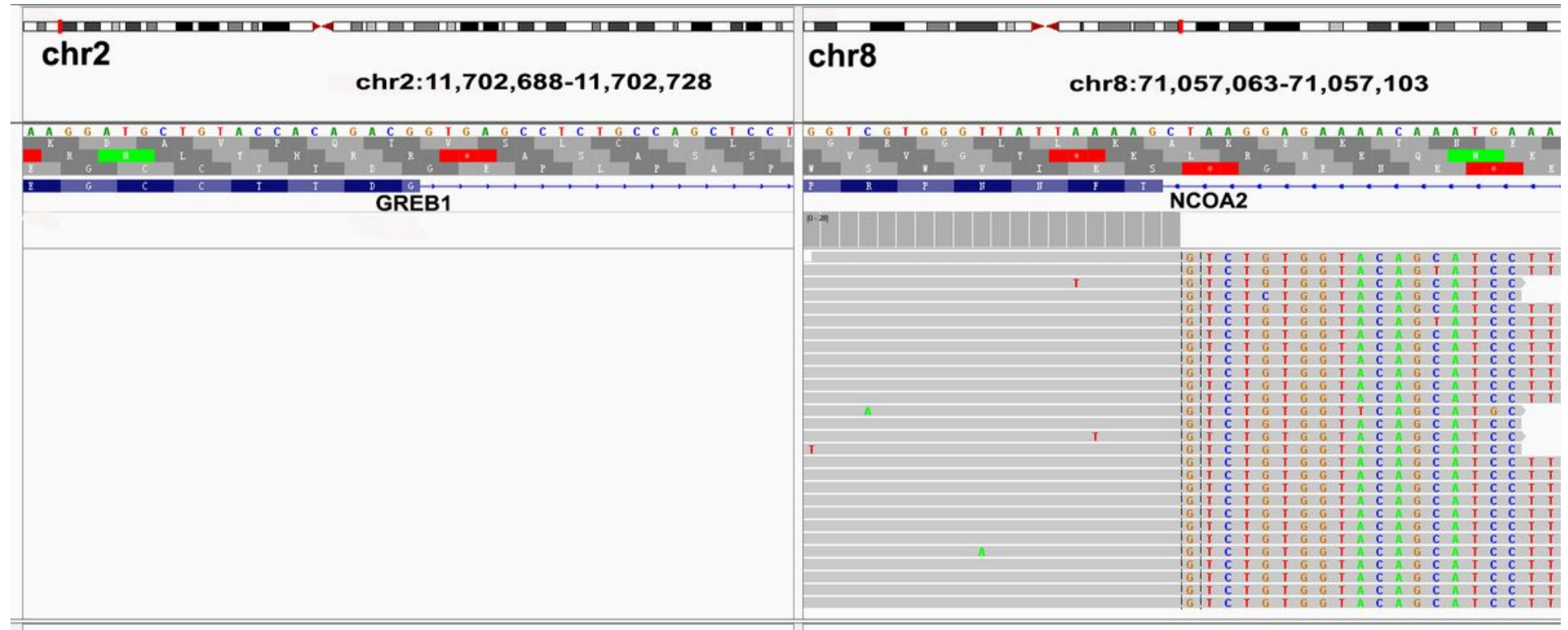


Detailed RNA sequencing of fusion junction reads confirmed the presence of the GREB1-NCOA2 fusion gene.

\section{Supplementary Files}

This is a list of supplementary files associated with this preprint. Click to download.

- CAREchecklistEnglish2013.pdf 